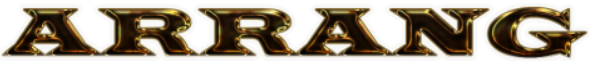

rrang, diambil dari bahasa Toraja yang mempunyai arti cahaya atau sinar. Arrang - Isebagai suatu sumber energi yang memancarkan sinar guna menerangi objek disekitarnya. Demikianlah cahaya kemuliaan Allah di perkenalkan melalui Pendidikan Agama Kris-
ten.

Turnal ARRANG adalah jurnal yang diterbitkan Sekolah Tinggi Agama Kristen Toraja, dengan tujuan menyebarluaskan gagasan-gagasan ilmiah dalam upaya mengimplementasikan pendidikan agama Kristen dalam dunia akademik maupun kemasyarakatan.

\section{JURNAL ARRANG}

\author{
Pelindung \\ KETUA STAKN TORAJA \\ Penanggungjawab \\ KEPALA P3M \\ Redaktur \\ MERY TOBAN, S.Th.,M.Pd.K \\ Editor \\ ALFRIDA LEPPE MEMBALA, M.Pd.K \\ Desain Grafis dan Layout \\ OKTOVIANUS PALUTE, S.Kom \\ Sekretariat \\ YUNITA ESTEVINE TONTA, SH. \\ AMBA RERUNG ALLO, SE.
}

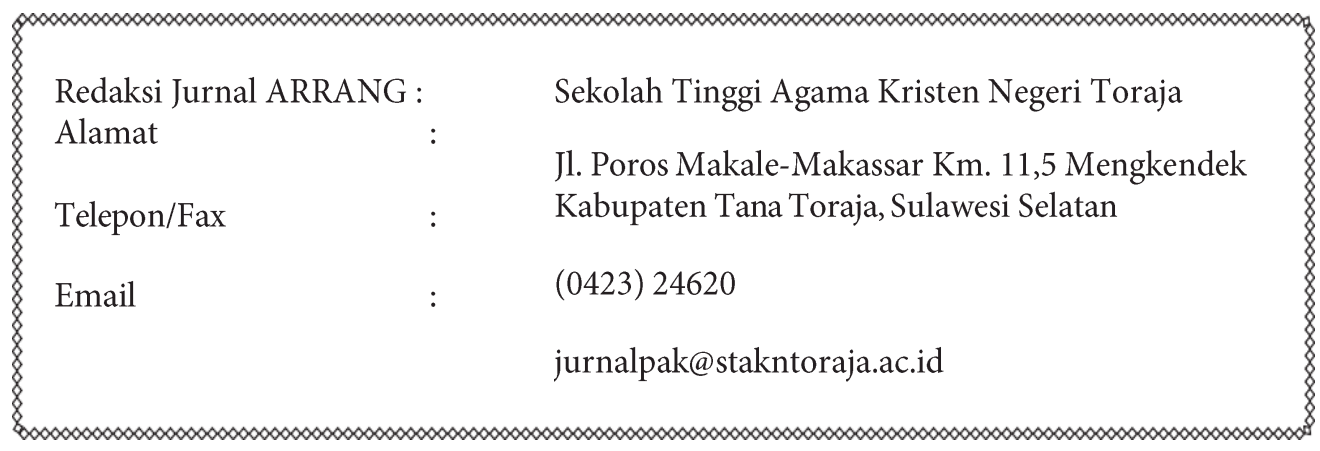




\section{PENgantaR RedaksI}

Salam untuk semua sidang pembaca,

Apa yang kuperintahkan kepadamu pada hari ini haruslah engkau perhatikan, haruslah engkau mengajarkannya berulang-ulang kepada anak-anakmu dan membicarakannya apabila engkau duduk di rumahmu, apabila engkau sedang dalam perjalanan, apabila engkau sedang berbaring, dan apabila engkau bangun. Haruslah juga engkau mengikatkannya sebagai tanda pada tanganmu dan haruslah itu menjadi lambang di dahimu, dan haruslah engkau menuliskannya pada tiang pintu rumahmu dan pada tiang pintu gerbangmu. (Ul. 6:6-9)

Terpujilah Allah, yang oleh anugerah dan kasih-Nya, memberikan kesempatan kepada setiap anaknya untuk dapat mengembangkan pikiran dan imannya sehingga dapat membuat tulisan baik artikel maupuan penelitian, yang dituangkan dalam jurnal ARRANG. Jurnal ARRANG mengungkapkan sebuah harapan dan kerinduan agar melalui kumpulan tulisan ini dapat menjadi sarana STAKN Toraja untuk menjadi berkat bagi sesama. Jurnal ARRANG merupakan hasil pemikiran dalam bidang Pendidikan Agama Kristen yang diterbitkan pada edisi Desember 2017, dengan tema: Revolusi Mental melalui Pendidikan diberbagai Lingkup. Tema ini diusung seiring dengan revolusi mental diberbagi bidang kehidupan termasuk bidang pendidikan oleh semua pelaksana pendidikan. Pelaksana pendidikan dimulai dari lingkup dalam rumah, selanjutnya gereja, sekolah, dan masyarakat. Hal ini akan menghasilkan generasi muda yang berkarakter baik dan kuat, untuk memajukan kehidupan bersama.

Adapun tujuan penerbitan jurnal ARRANG edisi ini, adalah untuk melaksanakan salah satu fungsi akademik STAKN Toraja, menjawab persoalan yang dialami dalam berbagai bidang kehidupan, berhadapan dengan globalisasi dan modernisasi. Mental peserta didik (generasi muda) dibentuk secara utuh sehingga dapat berperan dengan maksimal dalam pembangunan kehidupan pada semua lingkup.

Kami menyadari bahwa begitu banyak tuntutan yang harus dipenuhi untuk mengimbangi laju perkembangan arus teologi-pendidikan di era modern seperti yang terjadi sekarang ini. Sementara kemampuan kami sangat terbatas, karena itu kami mohon saran dan masukan dari pembaca demi perbaikan dan peningkatan kualitas jurnal berikutnya.

Akhirnya, kami mengucapkan terima kasih kepada segenap kontributor dan kepada semua pihak yang telah berperan dalam upaya penerbitan jurnal Pendidikan Agama Kristen Edisi Desember 2017

"Didiklah orang muda menurut jalan yang patut baginya, maka pada masa tuanya pun ia tidak akan menyimpang dari pada jalan itu." (Ams. 22:6).

Redaktur

Mery Toban, S.Th.M.Pd.K 


\section{DAFTAR ISI}

PENGANTAR REDAKSI

DAFTAR ISI

REVOLUSI MENTAL PENDIDIKAN KRISTEN

Kajian Etis tentang Pendidikan Kristen dalam menciptakan Akhlak Mulia

bagi Pengembangan Karakter Peserta Didik di Sekolah

Dr. Maidiantius $\tau_{\text {anyid, }} M$. Th. $_{\text {. }}$

INTERNALISASI PAHAM ANTI KORUPSI DALAM DUNIA PENDIDIKAN

Naomi Sampe, M. Th.

SIMBUANG KAYU

Ekspresi Dan Revitalisasi Nilai Ketorajaan

Dr. Abraham Sere Tanggulungan, M.Si.

PENDIDIKAN KRISTEN DALAM KELUARGA SEBAGAI UPAYA

PENANGGULANGAN KEMEROSOTAN MORAL ANAK

Dr. Lonatan Sumarto

PERANAN GURU DALAM REVOLUSI MENTAL PENDIDIKAN

BAGI ANAK KORBAN PERCERAIAN

Dames Anderson Lola, M. Th.

GURU PENDIDIKAN AGAMA KRISTEN SEBAGAI PELOPOR

REVOLUSI MENTAL

Marsi Bombongan Rantesalu, M. Th.

MEMBUDAYAKAN MENTALITAS ILMIAH

Revolusi Mental Dalam Dunia Pendidikan Kristiani di STAKN Toraja

Yohanes Krismantyo Susanta, M. Th.

PAK DI ERA CYBERTECHNOLOGY

Rannu Sanderan, M.Th.

GURU

Agen Perubah Mental

Dr. Osmail Banne Ringgi', M. Th.

TRANSFIGURASI PEMANGKU PENDIDIKAN YANG MEMBANGUN BERKESADARAN SECARA KONTEKSTUAL

Yanni Paembonan, M.PJ.K. 


\title{
GURU PENDIDIKAN AGAMA KRISTEN SEBAGAI PELOPOR REVOLUSI MENTAL
}

\author{
Marsi Bombongan Rantesalu
}

\begin{abstract}
The most effective pioneers of mental revolution are learners. Learners are the next generation of this nation, and learners who will take many roles in the development of the Indonesian nation. The advanced nation is determined by the person involved in the care of the Indonesian people, the advanced church is determined by the youth and members of the congregation who are actively involved in it. It is undeniable that changes within the church and within this nation are much influenced by the nation's children. Thus, the bachelors involved in the church and the state must be the nation's children who have good character, have a steel mental who will firmly fight for the Indonesian people and gerind from corruption, collusion, nepotism and other attitudes that can divide an alliance both in the church and in the nation. Therefore, the nation's children who are expected to bring change, are expected to be well educated, and have a commitment to be honest in advancing this nation, so teachers, especially Christian teachers who directly touching in educating the nation's children are expected to give its role as a destination planner mature learning, being a good example and able to create synergy between school and parents
\end{abstract}

Keywords: Planning, Modeling, Synergy

\section{A. PENDAHULUAN}

Pendidikan merupakan proses pengubah tingkah laku anak didik agar menjadi manusia dewasa yang mampu hidup mandiri. Guru sebagai bahagian yang terlibat langsung dalam proses pendidikan itu, sangat diharapkan mampu mengambil peranan yang seuai dengan tanggung jawab yang diembannya. Pendidikan tidak hanya mencakup pengembangan intelektualitas saja, akan tetapi lebih ditekankan pada proses pembinaan kepribadian peserta didik secara menyeluruh sehingga anak menjadi lebih dewasa. Guru sejatinya bukan sembarang pekerjaan, melainkan profesi yang pelakunya memerlukan berbagai kelebihan, baik terkait dengan kepribadian, akhlak, spiritual, pengetahuan dan keterampilan. Peran guru bukan sekadar mentransfer pelajaran kepada peserta didik. Tapi lebih dari itu guru bertanggungjawab membentuk karakter peserta didik sehingga menjadi generasi yang cerdas, saleh, dan terampil dalam menjalani kehidupannya.

Dengan menekankan pada pembinaan kepribadian maka peserta didik diharapkan meneladani apa yang dilakukan oleh pendidik (guru). Guru merupakan panutan ataupun 
teladan. Keteladanan seorang guru mencerminkan bahwa segala tingkah lakunya, tutur kata, sifat, maupun cara berpakaian semuanya dapat diteladani. Dewasa ini kehadiran guru sebagai pendidik semakin nyata menggantikan sebagian besar peran orang tua yang notabene adalah pengemban utama. Karenanya, di pundak guru terletak salah satu beban untuk merestorasi karakter dan kepribadian mulia bangsa Indonesia yang telah berada pada titik nadir. Guru diharapkan bisa mengembalikan peradaban bangsa yang tinggi, yang selama ini telah tergantikan dengan julukan bangsa yang korup, tidak memiliki kepribadian, bangsa yang kacau, jorok, bodoh, anarkis dan banyak atribut jelek lainnya yang kini melekat pada bangsa tercinta ini.

Peter Salim dan Yenni Salim mengungkapkan bahwa pendidikan adalah "proses perubahan cara berpikir atau tingkah laku dengan cara pengajaran, penyuluhan dan latihan; proses mendidik."111 Selanjutnya W.J.S. Poerwadarminta mengatakan, "Pendidikan adalah perbuatan (hal, cara dsb) mendidik,",112 sedangkan Dien Sumiyatiningsih mengatakan, "istilah pendidikan dalam literatur bahasa Indonesia adalah merupakan terjemahan dari bahasa Inggris yakni "education",

${ }^{111}$ Peter Salim dan Yenni Salim, Kamus Besar Bahasa Indonesia Kontemporer (Modern English: Jakarta, 1995), s.v. "didik".

${ }^{112}$ W.J.S Poerwadarminta, Kamus Umum Bahasa Indonesia (Jakarta: Balai Pustaka, 1985), s.v "didik". yang sebenarnya juga diambil dari bahasa Latin, "decure," yang berarti membimbing (to lead) dengan tambahan awalan "e" yang berarti keluar (out). Dengan demikian, arti kata pendidikan adalah suatu untuk membimbing keluar."113 Jadi pendidikan mengandung sebuah proses yang sistematis, terarah dan berkelanjutan untuk meningkatkan kualitas hidup seseorang.

Pengenalan pribadi Kristus dan menjadi serupa dengan Dia yang dinyatakan dalam kualitas hidup yang baik hanya didapatkan di dalam Pendidikan Agama Kriten. Oditha Hutabarat dkk mengatakan, "secara umum, Pendidikan Agama Kristen adalah usaha untuk membantu peserta didik tumbuh dan berkembang mencapai kepribadian utuh yang mencerminkan manusia sebagai gambar Allah yang memiliki kasih dan ketaatan kepada Tuhan, kecerdasan, keterampilan, berbudi pekerti luhur serta tanggung jawab dalam pembangunan bangsa dan negara."114 Dalam pernyataan John Calvin seperti yang dikutip oleh Paulus Lilik Kristianto dituliskan,

Pendidikan Agama Kristen adalah pendidikan yang bertujuan mendidik semua putera-puteri gereja agar

${ }^{113}$ Dien Sumiyatiningsih, Mengajar dengan Kreatif dan Menarik (Yogyakarta: Yayasan ANDI, 2006), 3-4.

${ }^{114}$ Oditha Hutabarat, Bahan Dasar Pendidikan Wawasan Kependidikan Guru Agama Kristen Sekolah Lanjutan Tingkat Pertama (Jakarta: Departemen Pendidikan dan Kebudayaan, 1999), 43. 
mereka terlibat dalam pengenalan Alkitab secara cerdas sebagaimana dengan bimbingan Roh Kudus, mengambil bagian dalam kebaktian dan memahami keesaan gereja, diperlengkapi untuk memilih cara-cara mengejawantakan kepribadian diri kepada Allah Bapa dan Yesus Kristus dalam pekerjaan sehari-hari serta hidup bertanggung jawab di bawah kedaulatan Allah demi kemuliaan-Nya sebagai lambang ucapan syukur mereka yang dipilih dalam Yesus Kristus." 115

Hal senada dikatakan oleh Werner C. Graendorf sebagaimana yang dikutip oleh Paulus Lilik Kristianto:

Pendidikan Agama Kristen adalah Proses pengajaran dan pembelajaran berdasarkan Alkitab, berpusat pada Kristus dan bergantung pada Roh Kudus, yang membimbing setiap pribadi pada semua tingkat pertumbuhan melalui pengajaran pada masa kini ke arah pengenalan dan pengalaman rencana dan kehendak Allah melalui Kristus di dalam setiap aspek kehidupan dan memperlengkapi mereka bagi pelayanan yang efektif yang berpusat pada Kristus sang guru agung dan perintah yang mendewasakan pada murid." 116

Pendidikan Agama Kristen haruslah berdasarkan pada Alkitab

\footnotetext{
${ }^{115}$ Paulus Lilik Kristianto, Prinsip dan Praktik Pendidikan Agama Kristen (Yogyakarta: Yayasan ANDI, 2006), 3. ${ }^{116}$ Ibid.
}

sebagai Firman Allah dan menjadikan Kristus sebagai pusat beritanya. Lanjut yang dijelaskan oleh Andar Ismail, "Pendidikan Agama Kristen sebagai tugas panggilan gereja adalah usaha untuk menumbuhkan dan mengembangkan kemampuan peserta didik agar dengan pertolongan Roh Kudus dapat memahami dan menghayati kasih Allah dalam Yesus Kristus yang dinyatakan dalam kehidupan sehari-hari terhadap sesama dan lingkungan hidupnya." 117

Jadi Pendidikan Agama Kristen adalah merupakan usaha orang tua, guru di sekolah, dan pihak gereja untuk mendidik peserta didik melalui proses pembelajaran berdasarkan Alkitab, berpusat pada Kristus dan bergantung pada Roh Kudus dengan demikian anak akan tumbuh dan berkembang mencapai pribadi yang utuh, dan cerdas secara spiritual.

\section{B. PERAN GURU PAK SEBAGAI PELOPOR REVOLUSI MENTAL}

\section{Merencanakan Pembelajaran Matang}

Dalam setiap aktivitas kehidupan seseorang senantiasa memerlukan perencanaan. Perencanaan dibutuhkan untuk menjadi pedoman langkahlangkah dari apa yang dikerjakan. Terry menyatakan bahwa perencanaan adalah menetapkan pekerjaan yang harus dilakukan/dilaksanakan oleh

${ }^{117}$ Andar Ismail, Ajarlah Mereka Melakukan (Bandung: BPK Gunung Mulia, 1998), 157. 


\section{JURNAL PENDIDIKAN AGAMA KRISTEN}

kelompok untuk mencapai tujuan yang digariskan."118 Oleh karena itu perencanaan juga mencakup kegiatan pengambilan keputusan. Udin Syaefudin Sa'ud mengatakan, "Pada hakikatnya perencanaan adalah suatu rangkaian proses kegiatan menyiapkan keputusan mengenai apa yang diharapkan terjadi (peristiwa, keadaan, suasana dan sebagainya) dan apa yang akan dilakukan (intensifikasi, ekstensifikasi,revisi, renovasi, substitusi, kreasi, dan sebagainya)."119 Rangkaian proses kegiatan dibuat sebagai patokan dalam mencapai tujuan aktivitas atau pekerjaan yang direncanakan.

Kaufman seperti yang dikutip oleh Harjanto mengatakan, "perencanaan adalah suatu proyeksi tentang apa yang diperlukan dalam rangka mencapai tujuan absah dan bernilai yang di dalamnya mencakup elemen-elemen:

1. Mengidentifikasi dan mendokumentasikan kebutuhan

2. Menentukan kebutuhankebutuhan yang perlu di prioritaskan

3. Spesifikasi rinci hasil yang dicapai dari tiap kebutuhan yang diprioritaskan

4. Identifikasi persyaratan untuk mencapai tiap-tiap pilihan

5. Sekuensi hasil yang diperlukan untuk memenuhi kebutuhan yang dirasakan

\footnotetext{
${ }^{118}$ Ibid

${ }^{119}$ Udis Syaifuddin Sa'ud Perencanaan Pendidikan
}

6. Identifikasi strategi alternatif yang mungkin dan alat untuk melengkapi tiap persyaratan dalam mencapai tiap kebutuhan, termasuk di dalamnya merinci keuntungan dan kerugian dari strategi dan alat yang dipakai."120

Dalam hal ini perencanaan berkaitan dengan penentuan apa yang akan dilakukan, dan bagaimana langkah-langkah untuk mencapai apa yang dilakukan tersebut. Dalam proses pembelajaran, perencanaan adalah hal yang sangat dibutuhkan dalam proses pembelajaran, perencanaan yang matang akan memudahkan seseorang dalam melaksanakan proses pembelajaran. perencanaan yang matang akan memberikan efektif dan efesiensi waktu dalam melaksanakan proses pembelajaran. Jadi perencanaan adalah Perencanaan adalah suatu proses penentuan langkah yang ditempuh secara sistematis untuk mencapai tujuan atau sasaran tertentu yang ingin dicapai

Selanjutnya tentang pengajaran. Pengajaran oleh Mulyani Sumantri seperti yang dikutip oleh A. Majid adalah, "Suatu proses yang dilakukan oleh guru dalam membimbing, membantu dan mengarahkan peserta didik untuk memiliki pengalaman belajar. Dengan kata lain pengajaran adalah suatu cara

\footnotetext{
${ }^{120}$ Harjanto, Perencanaan Pengajaran (Jakarta: Rineka Cipta, 2008), 2.
} 
bagaimana

mempersiapkan

pengalaman belajar bagi peserta didik.".121 Jadi Perencanaan pembelajaran adalah suatu proses kegiatan dalam merumuskan tujuan yang ingin dicapai dalam suatu kegiatan pembelajaran.

Guru Pendidikan Agama Kristen sebagai perencana dalam merencanakan program pembelajaran haruslah teliti, dengan merumuskan tujuan pembelajaran yang ingin dicapai. Pendidikan Agama Kristen mempunyai tujuan penting seperti yang dikemukakan oleh J.M. Nainggolan yaitu, "pertobatan, pertumbuhan Rohani, pemuridan, pembentukan spiritual dan penginjilan."122 Tujuan Penting dari Pendidikan Agama Kristen ini akan penulis uraikan sebagai berikut:

\section{Pertobatan}

Pertobatan berasal dari kata dasar "tobat" yang berarti sadar dan menyesal akan dosa (perbuatan yang salah atau jahat) dan berniat akan memperbaiki tingkah laku dan perbuatan, sedangkan pertobatan adalah perihal bertobat." ${ }^{23}$ Pertobatan adalah hal yang sangat penting dalam iman Kristen. Pendidikan Agama Kristen disekolah sering kali mengalami kegagalan karena tidak mementingkan nilai-nilai pertobatan J.M Nainggolan mengatakan, "pertobatanlah yang memungkinkan tiap-tiap orang

\footnotetext{
${ }^{121}$ Ibid

${ }^{122}$ J.M Nainggolan, Strategi Pendidikan Agama Kriten (Jabar: IKAPI, 2008), 3-5.

${ }^{123}$ Kamus Besar Bahasa Indonesia Kontemporer, s.v "tobat".
}

dapat melihat kerajaan Allah dan mengalami kelahiran baru dalam Kritus." $124 \quad$ Alkitab sabda menjelaskan pertobatan adalah pembaharuan hidup sehingga kembali kepada Tuhan, perubahan total sehingga yang lama ditinggalkan."125 Firman Allah yang diajarkan akan menghasilkan perubahan atau pertobatan bagi setiap orang, yaitu perubahan yang sesuai dengan Firman Allah. Pendidikan Agama Kristen bertujuan untuk menjadikan para peserta didik mengalami pertobatan yang sesungguhnya di dalam Yesus Kristus.

Jadi Pendidikan Agama Kristen yang diperankan oleh Guru PAK, membawa peserta didik mengalami pertobatan yakni mengalami kelahiran baru dalam Kritus, sadar dan menyesal akan dosa dan berniat akan memperbaiki tingkah laku dan perbuatan sehingga kembali kepada Tuhan, perubahan total sehingga yang lama ditinggalkan. Dalam hal ini guru PAK dalam proses pembelajaran, yang dirancangkan dalam perencanaan pembelajaran haruslah membawa siswa untuk mengalami kelahiran baru di dalam Yesus Kristus.

\section{Pertumbuhan Rohani}

Pertumbuhan rohani adalah proses menjadi makin serupa dengan Yesus Kristus."126 Pertumbuhan rohani dinyatakan

\footnotetext{
${ }^{124}$ Ibid.

${ }^{125}$ http://alkitab.sabda.org/about.php, diakses 25 September 2017.

${ }^{126}$ http://www.gotquestions.org/Indonesia /pertumbuhan-rohani.html, diakses 25 September 2017
} 
dengan makin nyatanya buah Roh dalam kehidupan orang percaya ketika terjadi perubahan hidup karena diselamatkan. Pertumbuhan rohani dimulai pada saat Roh Kudus berdiam di dalam kita (Yoh. 14:16-17). Kita adalah ciptaan baru di dalam Kristus (2Kor. 5:17). Pribadi lama kita digantikan dengan yang baru ( $R m$. 6-7). Pertumbuhan rohani adalah proses seumur hidup yang terjadi melalui mempelajari dan menerapkan Firman Tuhan (2Tim. 3:16-17), dan berjalan dengan Roh (Gal. 5:16-26)

Dalam kitab Ef. 4: 11-13 yang berbunyi dan Ialah yang memberikan baik rasul-rasul maupun nabi-nabi, baik pemberita-pemberita Injil maupun gembala-gembala dan pengajarpengajar, untuk memperlengkapi orang-orang kudus bagi pekerjaan pelayanan, bagi pembangunan tubuh Kristus, sampai kita semua telah mencapai kesatuan iman dan pengetahuan yang benar tentang Anak Allah, kedewasaan penuh, dan tingkat pertumbuhan yang sesuai dengan kepenuhan Kristus . Hal senada di ungkapkan oleh Warren W. Wiersbe mengatakan, “" Ia melihat tubuh Kristus yang terdiri dari semua orang percaya yang lambat laun bertumbuh sampai mencapai kedewaaan rohani, pertumbuhan yang sesuai dengan kepenuhan Kristus."127 Lanjut B.S. Sidjabat mengatakan "Tujuan Pendidikan Agama Kristen haruslah membimbing peserta didik agar percaya dalam hati dan mengakui dengan mulut serta menyatakan dalam perilaku bahwa Yesus Kristus adalah Tuhan dan

${ }^{127}$ Warren W. Wiersbe, Kaya di Dalam Kristus (Bandung: Yayasan Kalam Hidup, 2002), 97-98.
Juruselamat.",128

Hal

ini menunjukkan tujuan Pendidikan Agama Kristen yang sesungguhnya yaitu mendewasakan seseorang secara spiritual yang ditunjukkan dalam sikap dan tingkah lakunya yang sesuai dengan Firman Tuhan.

Dengan demikian dalam perencanaan tujuan pembelajaran guru berperan penting dalam merumuskan pertumbuhan rohani yang merupakan proses seumur hidup yang terjadi melalui mempelajari dan menerapkan Firman Tuhan sehingga mengalami kedewasaan penuh dan makin serupa dengan Yesus Kristus.

\section{Pemuridan}

Pemuridan merupakan kata dasar dari "murid" yang berarti orang (anak) yang sedang berguru (belajar, bersekolah) "129. Hal senada diungkapkan oleh E. Tambunan dan Edy. D.H. Siahaan mengatakan, " arti menjadi murid Yesus adalah penyerahan diri secara mutlak kepada Yesus," 130 pemuridan adalah amanat agung Yesus Kristus bagi semua orang percaya, Bram Soei Ndoen dalam bukunya Kingdom Discipleship Commission mengatakan,

Kata Murid memiliki dua pengertian (Mat 28:19-20) Pertama, Murid secara keabsahan Theologis, berarti mereka yang telah menjadi pemercaya Kristus. "Pergilah

${ }^{128}$ B.S. Sidjabat, Menggajar Secara Profesional (Bandung: Kalam Hidup, 2009), 178.

\footnotetext{
${ }^{129}$ Kamus Besar Bahasa Indonesia kontemporer, s.v "murid".

${ }^{130}$ E. Tambunan dan Edy. D. H. Siahaan, Pendidikan Agama Kristen (Pelita hati SMK Kelas X) (Medan: Mitra Medan, 2007), 94.
} 
jadikan semua bangsa murid$\mathrm{Ku}$ dan baptislah mereka dalam nama Bapa dan Anak dan Roh kudus,..." ini adalah fase penginjilan dan pemenangan jiwa menjadi pemercaya dan pengikut Kristus. Kedua, Murid dalam konteks strategi pengembanga n sumber daya manusia dari bahasa Yunaninya Mathetes, artinya seorang yang belajar melalui praktek (magang) untuk bukan sekedar tahu tapi menjadi cakap dan handal dan ajarlah mereka melakukan segala sesuatu yang telah kuperintahkan kepadamu."131

Lanjut Paulus Lilik Kristianto mengatakan, "tujuan mengajar adalah adalah agar dapat mengajar kepada orang lain, inilah yang dimaksud dengan pemuridan." 132 Bangsa Yahudi memiliki tradisi pemuridan yang kuat, dimulai dari keluarga. Orang tua diwajibkan untuk mengajarkan hukum Taurat yang terutama secara berulang-ulang kepada anak-anak mereka (Ul. 6:4-9). Selanjutnya proses pemuridan (pembelajaran) diikuti di sekolah dan menjadi murid khusus dari seorang rabi (guru keluaran sekolah keimaman). Di dalam seluruh alkitab perjanjian baru, kata "murid" tercatat 269 kali, sedangkan kata "Kristen" hanya tercatat 3 kali, dan itu menujuk kepada murid-murid Kristus. Berarti menjadi murid, adalah hal yang penting dalam kekristenan.

${ }^{131}$ http://kingdomdiscipleshipchurch.blog spot.com/2012/10/paradigma-pemuridankerajaan.html, diakses 25 September 2017

\footnotetext{
${ }^{132}$ Paulus Lilik Kristianto, op-cit., 6.
}

Pemuridan dalam konteks Pendidikan Agama Kristen adalah menjadi pembelajar melalui seorang pemurid yang mengajarkan kita bagaimana menjadi pengikut Kristus. James Kennedy mengatakan, "seorang murid adalah pengikut Yesus Kristus yang bisa berfungsi menghasilkan dan mendewasakan murid baru." 133 Jadi Guru Pendidikan Agama Kristen berperan merumuskan tujuan pembelajaran yakni Pemuridan yaitu pola pengasuhan rohani melalui proses pemuridan pengembangan karakter di dalam sebuah komunitas ke arah keserupaan dengan Kristus Guru Agung.

\section{Pembentukan Spiritual}

Tujuan menentukan tujuan pembelajaran, guru agama kristen dituntut secara khusus untuk membentuk spiritual peserta didik yang kokoh. Menurut Kamus Bahasa Indonesia Kontemporer spiritual adalah," berkenaan dengan spirit atau jiwa."134 Sedangkan pembentukan adalah, "proses dan cara membentuk."135 Jadi pembentukan spiritual adalah proses dan cara membentuk jiwa seseorang. Guru PAK, mengambil peran dalammenentukan tujuan pembelajaran yang hendak dicapai yaitu membentuk spiritual peserta didik. Pembentukan spiritual hendaknya menjadi bekal

${ }^{133}$ D. James Kennedy, Ledakan Penginjilan ( Jakarta Timur: IFTK Jaffray), 175.

\footnotetext{
${ }^{134}$ Peter Salim dan Yenny Salim, Op cit, s.v "spiritual".

${ }^{135}$ Peter Salim dan Yenni Salim, Op cit, S.V " pembentukan".
} 


\section{JURNAL PENDIDIKAN AGAMA KRISTEN}

yang utama bagi seorang peserta didik untuk menghadapi tantangan jaman. M Nainggolan mengatakan isi pengajaran Pendidikan Agama Kristen di sekolah adalah untuk membantu peserta didik mengembangkan rohaninya dalam sikap dan perbuatan dan mengarah kepada pembentukan spiritual serta membimbingnya kearah kedewasaan rohani."136 Pembentukan Rohani diartikan sebagai proses yang dilakukan secara terus menerus, sistematis dan sadar untuk mencapai tujuan yang Tuhan inginkan yaitu menjadi serupa dengan Kristus dalam seluruh hidup melalui ketaatan pada Alkitab dan kekuatan yang diberikan oleh Roh Kudus. Pembentukan rohani peserta didik, haruslah berkesinambungan dan hal ini harus dilakukan dengan dasar yang kokoh, kuat dan benar. Adapun dasar dalam pembentukan kerohanian peserta didik, haruslah berdasarkan Alkitab yang merupakan dasar dari kurikulum pendidikan Agama Kristen dan dasar dari Pendidikan nilai-nilai kristiani.

\section{Penginjilan}

Penginjilan adalah salah satu bagian dari Pendidikan Agama Kristen. Makmur Halim mengatakan, " penginjilan atau evangelism, berasal dari kata dalam bahasa Yunani yakni "Euangelion", yang berarti good news atau kabar baik. Kabar baik yang dimaksudkan adalah Injil, The Gospel yang berisi berita keselamatan, berita pengampunan, berita perdamaian, dan berita pengudusan bagi orang

${ }^{136}$ J.M. Nainggolan, op-cit., 36. berdosa."137 Penginjilan juga sering diartikan sebagai "usaha untuk memberitakan kabar baik kepada orang-orang yang belum mengenal Yesus Kristus dengan tujuan agar mereka dapat menerima Dia sebagai Tuhan dan Juruselamat pribadi." 138 penginjilan adalah rancangan Allah, dan sebagai rancangan Allah, Allah telah merancangkan penginjilan sejak kekekalan dengan tujuan untuk kemuliaan Allah, Y. Tomatala mengatakan tujuan Allah dalam penginjilan itu adalah lengkap. Tujuan yang dimaksud adalah, tujuan operasional dari penginjilan ialah berhubungan dengan rencana Allah, Tujuan terminal atau tujuan tertinggi dari penginjilan yaitu adanya persekutuan Allah dengan umat-Nya secara harmonis dan utuh, dan tujuan utopi artinya teragung dari penginjilan yaitu kemuliaan bagi Allah." 139 Jadi dalam merumuskan tujuan pembelajaran guru seharuasnya mampu mendesainnya sedemikian rupa sehingga pada akhir pembelajaran, peserta didik akan mampu menyuarakan amanat agung yaitu penginjilan yakni usaha untuk memberitakan kabar baik yang berisi berita keselamatan, berita pengampunan, berita perdamaian, dan berita pengudusan bagi orang berdosa dan kepada orang-orang

${ }^{137}$ Makmur Halim, Model-model Penginjilan Yesus (Malang: Gandum Mas, 2003), 25.

${ }^{138}$ Y.Y. Tomatala, Penginjilan Masa Kini (Malang: Gandum Mas, 1997), 1.

${ }^{139}$ Y. Tomatala, Penginjilan Masa Kini 2 (Malang: Gandum Mas, 2004), 32. 
yang belum mengenal Yesus Kristus.

\section{Menjadi Teladan yang Baik}

Pengajaran yang paling efektif, tidaklah hanya terletak dari seberapa banyak yang disampaikan oleh guru, tidak hanya terletak dari seberapa banyak teori yang dikuasi tetapi oleh guru, namun pengajaran yang paling efektif adalaha teladan hidup yang ditunjukkan oleh guru. Guru adalah suri teladan, dan seharusnya menjadi teladan yang baik bagi murid-muridnya serta setiap orang yang ada di sekitarnya. Secara khusus guru Pendidikan Agama Kristen lebih banyak dikenal sebagai teladan yang baik dari segi tutur kata, tingkah laku dan cara bersosialisasi dengan orang banyak. Guru itu ditiru segala tindak tanduknya dan menjadi panutan bagi anak didik maupun orang disekitarnya.

Guru Agama Kristen sebagai pelopor revolusi mental dalam menjalankan tugas tanggung jawabnya, harus menjadi teladan. Agus Wibowo mengatakan, "teladan sesungguhnya memiliki makna sebagai suatu proses mengajar, hubungan dan interaksi selama proses pendidikan, yang kemudian pada hari ini atau masa depan senantiasa ditiru... dalam sebuah proses belajar, sadar atau tidak maka perilaku seorang guru akan menjadi komunikasi (penyampaian pesan) paling efektif dan pengaruhnya sangat besar terhadap anak didik" ${ }^{140}$ dari hal ini menyingkapkan bahwa dalam proses belajar, dalam

${ }^{140}$ Agus Wibowo, Menjadi Guru Berkarakter (Yogyakarta: Pustaka Belajar, 2012), 55 proses berkomunikasi dan bertingkalhlakulah guru dapat dikatakan menjadi teladan.

Dalam hal keteladanan, guru Pendidikan Agama Kristen harus menjadi teladan dalam perkataan, perbuatan dan akhlaknya. Tingkahlaku seorang guru harunya menjadi realisasi dari apa yang diucapkan dan apa yang diperintahkan untuk dilakukan, sebagai teladan, guru harus terlebuh dahulu melakukannya yang kemudian diikuti oleh peserta didik dan orang yang ada disekitarnya. Kata-kata yang diucapkan oleh seorang guru sebenarnya merupakan cerminan dari ilmunya dan kepribadiannya, integritas seorang gurulah yang menjadi teladan yang sangat mulia, kesatuan kata dan perbuatannya, jujur, sabar dan iklas dalam segala keadaan merupakan hal patut untuk ditiru. Jadi keteladanan guru Pendidikan Agama Kristen, terletak dari tutur kata, tingkahlaku dan akhlaknya yang tergambar dari sikap hidupnya setiap saat dan dimanapun.

\section{Sinergitas Guru PAK dan Orang Tua}

Keberhasilan dalam proses pendidikanadalah jika terjadi kerjasama antara lembaga yang melaksanakan pendidikan itu. Masalah besar yang banyak dijumpai menyangkut masalah pendidikan adalah tidak adanya sinergitas antara pendidik primer dalam keluarga dan pendidik sekunder yaitu lembaga sekolah. Masalah ini mengakibatkan anak tidak mampu secara sistematis dan berkesinambungan serta terarah kepada tujuan yang terpenting 


\section{JURNAL PENDIDIKAN AGAMA KRISTEN}

dari pendidikan anak yaitu pendidikan holistik, menyeluruh yang menyangkut segala sisi kehidupan anak. Adanya sikap lepas tanggung jawab orang tua terhadap pendidikan anak membuat para orang tua menyerahkan sepenuhnya pendidikan anak kepada pihak sekolah yang pada akhirnya jika terjadi tindakan penyimpangan yang dilakukan oleh anak akan membuat orang tua menyalahkan guru, bahkan tidak dapat disangkali kasus pendidikan kepada anak yang disertai dengan sentuhan fisik membuat orang tua menyalahkan guru sepenuhnya. Hal-hal seperti ini terjadi oleh karena kurangnya kerjasama yang baik antara guru dan orang tua, tidak adanya kesepahaman tentang cara mendidik yang baik dan benar antara orang tua dan guru.Sinergitas antara pendidik primer yaitu orang tua dan pendidik sekunder yakni pihak sekolah haruslah sejalan. Kerjasama antara guru dan orang tua dalam masalah pendidikan nilai-nilai kristiani terhadap anak dapat ditingkatkan dengan adanya buku penghubung antara orang tua dan pihak sekolah dalam hal ini wali kelas, guru Bimbingan Konseling, dan Pendidik Kristen yaitu guru Agama Kristen, selain itu keaktifan orang tua dalam mengkomunikasikan keberadaan anaknya kepada pihak sekolah adalah hal yang sangat penting.

Membangun komunikasi yang baik antara orang tua dan guru dan memberikan pendidikan mengenai nilai-nilai kristiani terhadap anak patut untuk dilakukan dan senantiasa ditingkatkan. Banyaknya siswa yang melanggar di sekolah diakibatkan karena kurangnya perhatian orang tua terhadap anak, bahkan panggilan kepada orang tua melalui surat untuk membicarakan keberadaan anaknya tidaklah diindahkan. Komunikasi antara orang tua dan guru sangatlah membantu dalam memberikan pendidikan kepada anak. Komunikasi yang baik, serta pemahaman yang sama mengenai pentingnya pendidikan holistik terhadap anak dari orang tua dan guru akan sangat membantu anak untuk memahami dan melakukan nilai-nilai kristiani yang diajarkan dan diteladankan oleh guru maupun orang tua.

\section{C.PENUTUP}

Guru adalah pelopor revolusi mental, hal ini terjadi oleh karena gurulah yang bersentukan langsung dalam pengembangan watak dan karakter peserta didik. Peserta didik adalah generasi penerus bangsa, generasi penerus gereja, harapan bangsa, gereja dan terutama keluarga. Penyelamatan terhadap karakter bangsa yang sekarang ini semakin mengalami kemerosotan dapat terjadi jika generasi penerusnya dipersiapkan dengan baik dengan mental dan karakter yang baik dan sesuai dengan Pancasila dan ajaran agama.

Dalam proses pendidikan dan pengajaran, Guru Agama Kristen diharapkan untuk mampu mengambilperan dalam memperbaiki generasi penerus bangsa ini. Hal ini sangat tepat, mengingat dalam mata pelajaran Pendidikan Agama Kristen diajarkan nilai-nilai kristiani yang tentunya sejalan dengan Pancasila. 


\section{JURNAL PENDIDIKAN AGAMA KRISTEN}

Guru Agama Kristen bersentuhan langsung dengan pendidikan karakter anak sehingga dengan mudah bagi guru agama kristen untuk membentuk peserta didik memiliki karakter yang unggul dalam prestasi serta memiliki akhlak budi yang luhur. Penanaman nilai-nilai kristiani kepada peserta didik yang tepat akan menghasilkan peserta didik yang mampu berjuang dalam menghadapi ketidak adilan, ketidak jujuran, intoleran, korupsi, kolusi dan nepotisme. Penanaman nilai-nilai kristiani yang kokoh tidak akan mundur dalam mengahadapi permasalahanpermasalahan ini.

Dengan demikian sangat diharapkan bagi Guru Agama Kristen untuk mengambil peran yang baik dan tepat bagi pengembangan karakter peserta didik sebagai generasi penerus dan harapan bangsa, gereja, keluarga. Adapun peran yang dapat dilakukan adalah melalui perenacanaan pembelajaran yang baik dan benar, hal ini sangat penting, karena perenacanaan yang baik, benar, dan secara maksimal akan memudahkan dalam proses pengajaran, dengan perencanaan yang matang maka akan jelas tujuan yang ingin dicapai pada peserta didik, kemudian menjadi teladan yang baik bagi peserta didik, memberikan teladan dalam perkataan, dan perbuatan yang dimana hal ini senantiasa berproses dan terus menrus berlangsung, dan peran Guru Agama yang selanjutnya yaitu menciptakan sinergitas pendidikan antara Guru Agama Kristen dan Orang tua, sehingga dengan demikian pengajaran yang diberikan senantiasa berkelanjutan dan sistematis.

\section{DAFTAR PUSTAKA}

\section{Alkitab}

LAI.2002

\section{Buku-Buku}

Wibowo Agus, Menjadi Guru Berkarakter Yogyakarta: Pustaka Belajar, 2012

Ismail Andar, Ajarlah Mereka Melakukan Bandung: BPK Gunung Mulia, 1998

Sidjabat B.S., Menggajar Secara Profesional Bandung: Kalam Hidup, 2009

Kennedy D. James, Ledakan Penginjilan Jakarta Timur: IFTK Jaffray

Sumiyatiningsih Dien, Mengajar dengan Kreatif dan Menarik Yogyakarta: Yayasan ANDI, 2006

Tambunan E. dan Edy. D. H. Siahaan, Pendidikan Agama Kristen (Pelita hati SMK Kelas X) Medan: Mitra Medan, 2007

Harjanto, Perencanaan Pengajaran Jakarta: Rineka Cipta, 2008.
Nainggolan J.M, Strategi Pendidikan Agama Kriten Jabar: IKAPI, 2008.

Halim Makmur, Model-model Penginjilan Yesus Malang: Gandum Mas, 2003. 


\section{JURNAL PENDIDIKAN AGAMA KRISTEN}

Hutabarat Oditha, Bahan Dasar Pendidikan Wawasan Kependidikan Guru Agama Kristen Sekolah Lanjutan Tingkat Pertama Jakarta: Departemen Pendidikan dan Kebudayaan, 1999.

Kristianto Lilik Paulus, Prinsip dan Praktik Pendidikan Agama Kristen Yogyakarta: Yayasan ANDI, 2006.

Syaifuddin Udis Sa'ud Perencanaan Pendidikan

Wiersbe W Warren, Kaya di Dalam Kristus Bandung: Yayasan Kalam Hidup, 2002.

Tomatala Y., Penginjilan Masa Kini 2 Malang: Gandum Mas, 2004.

Tomatala .Y., Penginjilan Masa Kini Malang: Gandum Mas, 1997.

\section{Internet}

http://alkitab.sabda.org/about.ph p, diakses 25 September 2017.

http://kingdomdiscipleshipchurch. blogspot.com/2012/10/parad igma-pemuridankerajaan.html, diakses 25 September 2017

http://www.gotquestions.org/Indo nesia/pertumbuhan-rohani.html, diakses 25 September 2017

\section{Kamus}

Salim Peter dan Salim Yenni, Kamus Besar Bahasa Indonesia Kontemporer (Modern English: Jakarta, 1995.

Poerwadarminta W.J.S, Kamus Umum Bahasa Indonesia Jakarta: Balai Pustaka, 1985 


\title{
Membudayakan Mentalitas Ilmiah: Revolusi Mental Dalam Dunia Pendidikan Kristiani di STAKN Toraja
}

\section{Yohanes Krismantyo Susanta}

\begin{abstract}
This paper shows that one of the manifestations of the motto "mental revolution" promoted by President Jokowi's government in the context of higher education of theology can be done through the inculcation of spirit and the application of scientific mentality. That spirit is part of the Christian's struggle to transform into a new human being in the context of Christian education. Scientific mentality is one part that can not be separated from the world of education in Indonesia, including the educational institution of STAKN Toraja. This scientific mentality targets the community as a whole, both educators and students.
\end{abstract}

Keywords: mental revolution, Christian education, scientific mentality, STAKN Toraja

\section{Pendahuluan}

Pendidikan di masa kini menghadapi dan mengalami tantangan yang berat. Bukan hanya karena menghadapi masalahmasalah administratif dengan kurikulum yang berganti-ganti dan semakin mahalnya biaya pendidikan, namun benar-benar harus berjuang dan terlibat langsung dalam memperbaiki mentalitas masyarakat. ${ }^{141}$ Sekolah sebagai sarana pendidikan merupakan salah satu pusat budaya yang diharapkan ikut memberikan adil di dalam kehidupan suatu masyarakat dan bangsa.

Terkait dengan itu, salah satu program pemerintahan presiden Joko Widodo dikenal dengan slogan "revolusi mental."

${ }^{141}$ Radjiman Sitopu, "Pendidikan Nilai Bela Rasa Kristiani: Sebuah Perspektif Filosofis," Jurnal Proklamasi Vol. 6 (20042005): 6 .
Suatu perubahan dari aspek mental. Terkait dengan dunia pendidikan, mental seseorang yang terdidik dan sedang menerima pendidikan itu sendiri memang mesti ditempa sedemikian rupa agar menghasilkan manusia yang tidak sekadar berprestasi unggul, namun memiliki mental yang baik. Berangkat dari persoalan serta tujuan tersebut, maka tulisan ini hendak menyorot pentingnya mentalitas ilmiah dalam pendidikan khususnya pada konteks STAKN Toraja.

Hal ini penting sebab belum berevolusi" - sejauh observasi atau pengamatan penulis selama ini - masih kurang dapat dijumpai dalam lembaga pendidikan Kristen tersebut. Entah di kalangan tenaga pendidik dan kependidikan sendiri maupun di kalangan mahasiswa. Uraian lebih jauh terkait masalah ini akan dijelaskan pada bagian 


\section{JURNAL PENDIDIKAN AGAMA KRISTEN}

pembahasan dari tulisan ini. Oleh karena itu, tulisan ringkas ini diharapkan dapat menjadi otokritik bagi pendidikan tinggi teologi guna mengupayakan, memperjuangkan, dan menerapkan spirit mentalitas ilmiah dalam pendidikan teologi sebagai bagian yang tidak dapat dipisahkan dari cita-cita nasional yang diusung oleh pemerintah Negara Kesatuan Republik Indonesia.

\section{Revolusi Mental}

Sejak tahun 2014 istilah "revolusi mental" menjadi begitu familiar di kalangan masyarakat Indonesia, saat figur calon presiden Jokowi kala itu mengumandangkannya sebagai salah satu program prioritas pemerintahannya yang disebut dalam Nawa Cita, yang berarti "delapan cita- cita". Dengan dilatari oleh kemandegan bahkan keterpurukan pembangunan yang terjadi di tengah Negara Kesatuan Republik Indonesia, revolusi mental dicanangkan untuk menghasilkan kebangkitan nasional bagi individu dan bangsa yang berkarakter, mandiri dan beridentitas. 142 Karakteristik demikian adalah fondasi bagi kemartabatan Indonesia dalam kompetisi di dunia global.

Salah satu agenda dalam Nawa Cita yang paling banyak dibahas oleh publik adalah poin nomor 8 yakni, revolusi karakter yang biasa disebut revolusi mental. Apa itu revolusi mental? Jokowi

\footnotetext{
${ }^{142}$ Mulyo Kadarmanto, "Mengkaji
} Revolusi Mental dalam Perspektif Pendidikan Kristiani," Polygot: Jurnal Universitas Pelita harapan Vol. 12 No. 1 (Januari 2016): 103. menjelaskan bahwa arti dari revolusi mental yang dia gagas adalah menggalakkan pembangunan karakter untuk mempertegas kepribadian dan jati diri bangsa sesuai dengan amanat Trisakti Soekarno. Untuk mencapai tujuan tersebut, menurut Jokowi, sistem pendidikan harus diarahkan untuk membantu membangun identitas bangsa Indonesia yang berbudaya dan beradab, yang menjunjung tinggi nilai-nilai moral agama yang hidup di Indonesia.

\section{Dalam kehidupan sehari-} hari, praktek revolusi mental adalah menjadi manusia yang berintegritas, mau bekerja keras, dan punya semangat gotong royong. Revolusi Mental adalah suatu gerakan untuk menggembleng manusia Indonesia agar menjadi manusia baru, yang berhati putih, berkemauan baja, bersemangat elang rajawali, berjiwa api yang menyala-nyala. ${ }^{143}$

Secara singkat 3 nilai revolusi mental yang ditekankan yaitu:

-Integritas (jujur, dipercaya, berkarakter, bertanggungjawab)

-Kerja keras (etos kerja, daya saing, optimis, inovatif, dan produktif)

-Gotong royong (kerjasama, solidaritas, komunal, berorientasi pada kemaslahatan).

Dari uraian singkat di atas jelas gerakan revolusi mental lebih berisikan pendidikan nilai atau

${ }^{143}$ Kominfo, "Revolusi Mental: Membangun Jiwa Merdeka Menuju Bangsa Besar,"

https://www.kominfo.go.id/content/detail/5932/r evolusi-mentalmembangun-jiwa-merdekamenuju-bangsa-besar/0/artikel_gpr) (diakses 13 Oktober 2017). 


\section{JURNAL PENDIDIKAN AGAMA KRISTEN}

pendidikan karakter yang dalam situasi bangsa Indonesia sekarang sangat penting untuk dilakukan secara serentak agar bangsa ini tetap kuat, maju, dan bersatu. Nilai karakter itu terutama nilai integritas, kerja keras, dan gotong royong.

Istilah "revolusi," biasanya digunakan untuk mengartikan satu gerakan massal yang dilakukan untuk mengakhiri satu kekuasaan pemerintahan dan itu merupakan perjuangan berat (pertumpahan darah) dan yang seringkali dilakukan dengan kekerasan. Kamus Merriam Webster memberikan pengertian revolusi sebagai "the usually violent attempt by many people to end the rule of one government and start a new one." Selain itu, revolusi juga berarti " a sudden, extreme, or complete change in the way people live, work"; or fundamental change in the way of thinking about or visualizing something: a change of paradigm." Sedangkan, istilah "mental" berasal dari kata Latin yaitu "mensment", yang kemudian dalam bahasa Inggris menjadi istilah "mind", yang dapat berarti pikiran atau akal. Kamus Merriam-Webster menulis mental sebagai "of or relating to the mind; specifically: of or relating to the total emotional and intellectual response of an individual to external reality." Kendati istilah "revolusi" seringkali dipahami dalam konteks sosial politik sebagai satu gerakan atau proses yang radikal dengan pertumpahan darah; namun dalam konteks pikiran atau sisi keberadaan manusia, revolusi mental secara harafiah dapat didefinisikan sebagai satu perubahan pikiran atau paradigma yang terjadi secara radikal (ekstrim), yang bukan berarti disertai kekerasan dengan pertumpahan darah, tetapi perubahan radikal yang menunjukan suatu pembaharuan. ${ }^{144}$

Presiden Joko Widodo bersama Sindhunata sebagaimana dikutip oleh Wattimena mengatakan bahwa reformasi yang dilaksanakan di Indonesia sejak tumbangnya rezim Orde Baru Soeharto tahun 1998 baru sebatas melakukan perombakan yang sifatnya institusional. Ia belum menyentuh paradigma, mindset, atau budaya politik kita dalam rangka pembangunan bangsa (nation building). Agar perubahan benar-benar bermakna dan berkesinambungan, dan sesuai dengan cita-cita Proklamasi Indonesia yang merdeka, adil, dan makmur, kita perlu melakukan revolusi mental. ${ }^{145}$

\section{Revolusi Mental dan Iman Kristen}

Istilah "revolusi mental" tidak digunakan didalam Alkitab, tetapi untuk merujuk kepada pembaharuan yang seperti di maksud dari revolusi mental, Alkitab menggunakan istilah "transformasi". Kamus Besar Bahasa Indonesia mengartikan transformasi sebagai perubahan rupa yang mencakup bentuk, sifat dan fungsi. Roma 12 ayat 2, mengatakan "Janganlah kamu menjadi serupa dengan dunia ini, tetapi berubahlah oleh

\footnotetext{
${ }^{144}$ Kadarmanto, "Mengkaji Revolusi Mental,": 105.

${ }^{145}$ Reza A. A. Wattimena, "Revolusi

Doa dan Revolusi Mental,"

https://rumahfilsafat.com/2014/05/13/revolusidoa-dan-revolusi-mental/ (Diakses 13 Oktober 2017).
} 


\section{JURNAL PENDIDIKAN AGAMA KRISTEN}

pembaharuan budimu, sehingga kamu dapat membedakan manakah kehendak Allah: apa yang baik, yang berkenan kepada Allah dan yang sempurna". Istilah "berubahlah" berasal dari kata Yunani " $\mu \varepsilon \tau \alpha \mu о \rho \varphi о \tilde{\sigma} \theta \varepsilon$ " (metamorphouste), dengan kata

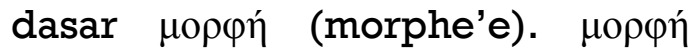
berarti "bentuk", 146 dalam hal ini secara literal merupakan bentuk yang mewujudkan esensi terdalam (batin) seseorang.

Helps Word Studies memberikan makna untuk istilah ini sebagai "changing form in keeping with inner reality," sedangkan dalam Vine's Expository memberikan pengertian "the obligation being to undergo a complete change which, under the power of God, will find expression in character and conduct; morphe lays stress on the inward change."147 Kedua pengertian tersebut memberikan penekanan pada perubahan yang mendalam dalam batin seseorang yang kemudian memang akan terekspresi dalam karakter dan perilaku seseorang, dan dalam pengertian yang kedua dengan tegas bahwa perubahan tersebut adalah dalam kuasa Allah atas seseorang. Searah dengan penjelasan tersebut, dalam menjelaskan makna tersebut, Greene melihat bahwa "Romans $12: 2$ is calling us to repentance, repentance means, a change of mind. And repentance is an

\footnotetext{
${ }^{146}$ Kadarmanto, "Mengkaji Revolusi Mental,": 106.

${ }^{147}$ Kadarmanto, "Mengkaji Revolusi

Mental,": 106.
}

ongoing quality of the Christian mind. ${ }^{148}$

Pertanyaan, apa saja yang perlu diubah, atau apa saja yang dimaksud dengan pertobatan dalam konteks ini? Ada banyak hal. Salah satunya adalah cara beriman kita, cara kita berdoa dan isi doa kita. Doa sendiri adalah bagian dari iman Kristen dan pengajaran gereja. Oleh karena itu tak heran ada adagium yang mengatakan "doa adalah nafas hidup orang beriman." Terkait dengan itu, ada sebuah ungkapan Lex orandi, lex credendi: bagaimana kita berdoa, itu menentukan bagaimana kita beriman dan percaya. Aksioma tersebut menegaskan bahwa aturan aturan dan hukum-hukum iman sangatlah ditentukan oleh bagaimana kita berdoa. Seperti dipaparkan Nico Koopman, profesor teologi sistematik dan etika di Universitas Stellenbosch, semasa rezim apartheid di Afrika Selatan, aksioma itu diperluas menjadi lex orandi, lex credendi,dan lex (con)vivendi. Artinya, bagaimana kita berdoa tidak hanya menentukan bagaimana kita beriman, tetapi juga bagaimana kita hidup, bahkan bagaimana kita hidup bersama. ${ }^{149}$ Di Afrika Selatan semasa rezim apartheid, doa dan upacara agama memang menjadi ambivalen. Doa bisa untuk menindas ataupun untuk membebaskan. Di bawah rezim represif, doa dan iman bahkan dilegitimasikan secara teologis untuk melestarikan penindasan.

${ }^{148}$ A. E. Greene, A transforming vision: Reclaiming the future of Christian Education (Colorado Springs: ACSI, 1998), 271

${ }^{149}$ Wattimena, "Revolusi Doa dan Revolusi Mental,” (Diakses 13 Oktober 2017). 
Karena itu, doa juga perlu dikoreksi secara etis. ${ }^{150}$

Doa harus bisa menjadi kekuatan kritis untuk mendobrak masyarakat yang tidak adil. Di sini, seperti diajakkan filsuf Nicholas Wolterstorff dari Amerika Serikat, kita perlu memahami kesucian itu bukan semata-mata dari kategori kesucian sendiri, tetapi juga dari kategori keadilan. Kata Wolterstorff, masyarakat yang tidak adil adalah masyarakat yang kehilangan keutuhannya. Dalam masyarakat ini sekelompok orang tersudut di pinggiran, dan tak terinkorporasikan ke dalam kehidupan yang sedang berkembang dalam masyarakat itu. ${ }^{151}$ Masyarakat demikian bukanlah citra atau cerminan dari Tuhan dalam keutuhan- Nya. Dalam keutuhan-Nya yang komunitarian, Tuhan tidak mengecualikan siapa pun. Karena itu, masyarakat yang tidak adil dan mengecualikan itu adalah masyarakat yang tidak suci. Maka, masyarakat baru yang kita cita citakan hendaklah menjadi masyarakat kesucian dan keutuhan, masyarakat di mana terjadi integritas dan komunitas, inklusi dan pemerataan keadilan, serta kesatuan hidup yang subur berkembang.

Doa Kristiani sesungguhnya selalu merindukan datangnya masyarakat semacam itu. "Datanglah kerajaan-Mu", itulah yang didoakan mereka dalam doa Bapa Kami, seperti diajarkan oleh Yesus sendiri. Maka, ahli kitab suci Afrika Selatan, William Domeris,

\footnotetext{
${ }^{150}$ Wattimena, "Revolusi Doa dan

Revolusi Mental," (Diakses 13 Oktober 2017).

${ }^{151}$ Wattimena, "Revolusi Doa dan Revolusi Mental," (Diakses 13 Oktober 2017).
}

mengungkapkan,

datanglah kerajaan-Mu itu adalah sebuah doa revolusioner. Doa ini menyerang jantung kejahatan di dunia, dan memaklumkan matinya segala macam bentuk penindasan, serta mengharap datangnya kerajaan baru di dunia. ${ }^{152} \mathrm{Hal}$ ini berarti pula bahwa dengan mendoakan "datanglah kerajaan-Mu", orang menatap berakhirnya zaman penindasan ini, dan pada saat yang sama, seperti diajakkan Yesus, bersama-sama mengusahakan tegaknya kerajaan baru sebagai realitas fisik, di mana penindasan diakhiri dan pembebasan Tuhan dimulai. Mendoakan "kedatangan kerajaan Tuhan" adalah melantunkan doa melawan pemerintah yang tidak adil.

\section{Revolusi Mental dalam Konteks STAKN Toraja: Membudayakan Mentalitas Ilmiah}

Bagaimana menerapkan
revolusi mental dengan cara
mengedepankan mentalitas ilmiah
di dunia kampus? Jalur pendidikan
merupakan jalur strategis untuk
internalisasi nilai-nilai revolusi
mental dalam mewujudkan
pendidikan karakter sebagai
pembentuk jati diri bangsa. Jalur
strategis ini memperlihatkan
bagaimana pendidikan adalah
locus revolusi mental, yang
merupakah wadah untuk
pembentukan karakter anak-anak
bangsa.

Melalui pembentukan karakter sejak dini, maka ini diharapkan menjadi titik mulai pelaksanaan revolusi mental. Dalam hal ini Supeli sebagaimana

${ }^{152}$ Wattimena, "Revolusi Doa dan Revolusi Mental," (Diakses 13 Oktober 2017). 


\section{JURNAL PENDIDIKAN AGAMA KRISTEN}

dikutip Kadarmanto menjelaskan bahwa "karakter yang baik adalah buah dari budi yang terdidik melalui penanaman kebiasaankebiasaan, dan kebiasaan melibatkan latihan-latihan fisik individual tentang perilaku serta tindakan yang baik." Melalui penanaman kebiasaan yang akan terpola dalam kehidupan perilaku, maka perubahan mendasar dalam mentalitas, semangat dan moralitas yang menjelma ke dalam perilaku dan tindakan sehari-hari akan menciptakan transformasi etos dalam revolusi mental. ${ }^{153}$ Penggunaan istilah "revolusi", tidak berlebihan. Sebab, Indonesia memerlukan suatu terobosan budaya politik untuk memberantas setuntas-tuntasnya segala praktikpraktik yang buruk yang sudah terlalu lama dibiarkan.

harus Mengapa mentalitas ilmiah
dibudayakan? Sulit bagi kita untuk berkembang jika tidak memiliki mentalitas ilmiah. Dalam arti ini, mentalitas ilmiah adalah sikap batin yang mencoba menerapkan cara berpikir ilmiah di dalam kehidupan sehari-hari. Syarat pertama dari mentalitas ilmiah adalah kemampuan untuk mengamati apa yang ada di kenyataan. Pada titik ini, pengalaman sehari-hari bukan hanya sebagai obyek untuk dilihat, tetapi sebagai sesuatu yang diamati dan didalami. Orang yang memiliki mentalitas ilmiah selalu berpikir bertolak dari pengalaman Mental,": yang diamati. Ia tidak hidup dalam takhayul, ataupun gossip. ${ }^{154}$

Jika sesorang berpijak dari pengamatan dan pengalaman, maka dengan sendirinya akan timbul rasa penasaran di dalam dirinya. Rasa penasaran menjadi awal dari kegiatan pembelajaran. Rasa penasaran muncul karena rasa kagum terhadap apa yang ada, atau apa yang terjadi, misalnya keindahan alam, keberadaan masyarakat, dan sebagainya.

Bentuk konkrit dari rasa penasaran adalah pertanyaan. Bertanya merupakan symbol dari tindak berpikir manusia. Pertanyaan yang bermutu akan jauh lebih berharga daripada jawaban-jawaban yang kaku, yang merasa sudah pasti akan rumusannya sendiri. Namun pertanyaan tidak boleh berhenti hanya menjadi pertanyaan. Ia menuntut pencaharian dan penelitian untuk mengajukan beberapa jawaban yang mungkin.

Pertanyaan menuntut dorongan untuk memahami lebih jauh, yakni untuk melampaui pengetahuan kita sebelumnya, untuk menjadi lebih dari sebelumnya. Untuk mencapai pemahaman, kita memerlukan metode, ${ }^{155}$ atau cara untuk

${ }^{154}$ Reza A. A. Wattimena, Filsafat Sebagai Revolusi Hidup (Yogyakarta, Kanisius, 2015), 107.

${ }^{155}$ Dalam studi ilmu teologi, misalnya Perjanjian Lama sangat memerlukan dan membutuhkan metode. Metode tersebut berguna sebagai alat untuk membantu menemukan interpretasi yang baru dan sesuai dengan konteks Asia. Dengan demikian, teologi yang ditawarkan berdasarkan interpretasi dengan metode yang dilakukan akan dipahami dan diharapkan dapat menjadi salah satu alternatif jawaban bagi realitas hidup di Asia. 
menjelajahi kenyataan di luar dan di dalam diri kita sendiri.

Metode yang terpenting
adalah metode berpikir dan
penarikan kesimpulan. Akal budi
dan logika adalah dasar dari
mentalitas ilmiah. Dua hal ini harus
ada agar mentalitas ilmiah
terbentuk. ${ }^{156}$ Keduanya berperan
besar di dalam penarikan
kesimpulan yang akhirnya juga
mendorong lahirnya tindakan.
Prinsip dasarnya: penarikan
kesimpulan harus sesuai dengan
pernyataan-pernyataan
sebelumnya, yang telah terbukti
kebenarannya.

Dalam tataran keilmuan, seorang ilmuan tidaklah boleh menjadikan teorinya sebagai kebenaran mutlak. Inilah yang disebut sebagai sikap anti dogmatis. Setiap teori dan kesimpulan harus dipertanyakan ulang, dan diuji lagi di hadapan kenyataan. 157

Dunia kampus adalah dunia menggali ilmu pengetahuan. Apa dan bagaimanakah pengetahuan itu? Manusia selalu berada pada tahap pencarian akan pengetahuan. Ketidakmungkinan untuk merasa mapan pada suatu titik pencarian, menjadikan manusia selalu berjalan dalam ritme ketidakpuasan.

\section{Pengetahuan}

adalah keseluruhan pemikiran, gagasan, ide, konsep, dan pemahaman yang dimiliki manusia tentang dunia dan segala isinya, termasuk manusia dan kehidupannya. Sedangkan ilmu pengetahuan adalah

\footnotetext{
${ }^{156}$ Wattimena, Filsafat Sebagai Revolusi Hidup, 108.

${ }^{157}$ Wattimena, Filsafat Sebagai
Revolusi Hidup, 108.
}

keseluruhan sistem pengetahuan manusia yang telah dibakukan secara sistematis. ${ }^{158}$ Ada pun yang menjadi tujuan ilmu pengetahuan, seperti yang dituliskan oleh J.J.M.Wuisman dalam bukunya Pengertian Ilmu-Ilmu Sosial, adalah mempelajari secara langsung kenyataan objektif dan mengembangkan penjelasan atasnya dalam bentuk hukum dan teori. ${ }^{159} \mathrm{Hal}$ ini berlaku bukan hanya bagi ilmu alam yang mempelajari gejala alam, tetapi juga terhadap ilmu-ilmu sosial yang mempelajari kehidupan masyarakat sebagai sebuah "fakta sosial". Dengan perkataan lain, menurut Wuisman, perlu dikembangkan suatu bahasa ilmu pengetahuan yang memungkinkan "fakta empiris" ditunjuk dan dijelaskan secara langsung serta mengungkapkan kebenaran objektif yang terkandung di dalamnya.

Dengan demikian, maka peranan bahasa menjadi sangat penting dalam mengartikulasikan kenyataan yang diteliti dan diobjektifasi secara sistematik sebagai ilmu pengetahuan. J.J.M Wuisman mengajukan sebuah perspektif yang menarik dalam ulasannya tentang bahasa dan pengetahuan. Perspektif yang ia pakai adalah perspektif konstruktivisme kritis. ${ }^{160}$ Paham konstruktivisme kritis menyakini nature dan human knowledge

${ }^{158}$ J. J. M. Wuisman, Pengertian Ilmuilmu Sosial. Azas-azas, Jilid 1 ( Jakarta: FEUI, 1996), 223.

${ }^{159}$ J. J. M. Wuisman, Pengertian Ilmuilmu Sosial. Azas-azas, Jilid 1 ( Jakarta: FEUI, 1996), 224.

${ }^{160}$ J. J. M. Wuisman, Pengertian Ilmuilmu Sosial. Azas-azas, Jilid 1 ( Jakarta: FEUI, 1996), 234. 
mampu mentransformasi dan merekonstruksi fenomena dan realita sosial ke dalam ilmu pengetahuan atau ilmu-ilmu sosial. Kunci pemikiran konstruktivisme kritis adalah bahwa dunia sosial adalah suatu konstruksi manusia.

Akan tetapi, konsep ilmu pengetahuan bukan merupakan hasil dari kesepakatan sosial, tetapi sesuatu yang dibangun secara kritis. Dan yang menarik, sebagaimana yang dinyatakan oleh Wuisman, bahwa setiap ilmuwan yang menegaskan pengetahuan ilimiahnya melalui bahasa selalu mesti terbuka terhadap pengujian. Sebab, tujuan penelitian ilimiah adalah berusaha menentukan secara tegas dan sistematis ketidak-benaran dari pada apa yang dinyatakan dalam bahasa ilmu pengetahuan. Dengan kata lain, menurut hemat saya, kebenaran (ilimiah) adalah sesuatu yang masih harus terus dicari.

Perihal

pencarian kebenaran (ilimiah) tersebut akan menjadi semakin menarik bila kita mengaitkannya dengan iman. Saya jadi teringat dengan apa yang dikatakan oleh Anselmus tentang "iman yang mencari pengertian". Sejauh ini kebanyakan gereja menjadi sangat dogmatis. Berbagai formulasi dogma yang sebetulnya merupakan sebuah hasil diskusi telah dibakukan dan dibekukan menjadi satu-satunya kebenaran, sehingga pencarian menjadi hilang. Daya kritis untuk mempertanyakan hasil-hasil diskusi ratusan tahun lalu menjadi tumpul. Alhasil, kebanyakan gereja menjadi tertutup serta kehilangan relevansi dan signifikansinya.
Saya kira di sinilah letak sumbangan pemikiran sang penulis bagi gereja untuk memperbaharui perspektif gereja dalam memandang kebenaran doktrin-doktrinnya. Gereja mesti terbuka dalam menyambut kebenaran-kebenaran baru. Atau, paling tidak, gereja mau mengkontekstualisasikan ajaranajarannya dengan kehidupan dewasa ini, agar kehadiran gereja menjadi relevan dan signifikan.

Kalau kebenaran ilimiah saja selalu memunculkan hal-hal baru yang mampu menggetarkan kita, apalagi Allah sebagai Sang Misteri? Karena itu, jangan memasung Allah dalam penjarapenjara kebenaran yang beku dan kaku, tetapi biarkan Ia tetap sebagai Sang Misteri, supaya kita terdorong untuk terus mencari Sang Kebenaran dalam bahasabahasa yang baru. Iman itu harus selalu mencari pengertian.

Bahkan Alkitab sendiri harus dipertanyakan. Ia bukanlah sebuah produk dogma yang kaku. Ia harus dilampaui. Melampaui dogmatism. Sebagai pengajar Perjanjian Lama, saya meyakini sungguh-sungguh Alkitab sebagai pedoman orang percaya, namun Alkitab itu sendiri tidak kebal dari kritik.

Alkitab adalah kitab suci umat Kristiani. Alkitab dipandang sebagai sumber kebenaran dan pegangan hidup. Istilah Firman Allah kemudian dilekatkan pada Alkitab. Menurut Robert Coote dan David Robert Ord, ada begitu banyak orang yang percaya dan meyakini bahwa Alkitab adalah kitab yang diinspirasikan secara ilahi, firman Allah, tanpa pernah 
mempertanyakan hal tersebut. ${ }^{161}$ Orang-orang tidak mengajukan pertanyaan, mengapa saya mempercayai hal itu? Mereka mempercayainya semata karena mendengar bahwa memang demikianlah sepatutnya. Mereka menduga bahwa sudah seperti itulah duduk perkaranya hanya karena semua orang mengatakannya, dan akibatnya tidak pernah mengkajinya lagi. Akibat lainnya, seseorang beriman secara buta, pokoknya begitu. Padahal, segala sesuatu perlu untuk ditanyakan.

Menurut Gerrit Singgih,
dalam Alkitab tidak ada
pemahaman yang bersifat
fatalistik. ${ }^{162}$ PL penuh dengan doa
orang beriman yang tidak segan-
segan bertanya kepada Tuhan,
sebab bertanya merupakan bagian
dari dialog umat dengan Tuhan. ${ }^{163}$

Hal ini sesungguhnya sesuai dengan semangat iman Kristen sebagaimana dikatakan oleh Anselmus, fides quaerrens intelectum; iman mencari pemahaman. Pemahaman itu juga dijelaskan kembali oleh Groenen yang mengatakan bahwa teologi menyangkut pemahaman yang bertanggung jawab mengenai iman umat percaya. Yang ingin dipahami adalah iman, baik dari sudut pandang manusia yang beriman maupun dari segi sasaran

${ }^{161}$ David Robert Ord dan Robert B. Coote, Apakah Alkitab Benar?, terj. Martin Lukito Sinaga (Jakarta: BPK Gunung Mulia, 2013), 121.

${ }^{162}$ Arti ungkapan tersebut adalah "menyerah kepada nasib."

${ }^{163}$ Emanuel Gerrit Singgih, Mengantisipasi Masa Depan (Jakarta: BPK Gunung Mulia, 2004), 222. iman itu, yaitu Allah dalam relasinya dengan manusia. ${ }^{164}$

Terkait dengan hal tersebut, Ioannes Rakhmat yang mengutip, Gautama Buddha, dalam web blog yang ia kelola mengatakan:

"Jangan percaya hal apapun hanya karena kamu telah mendengarnya. Jangan percaya hal apapun hanya karena hal itu telah dibicarakan dan digunjingkan oleh banyak orang. Jangan percaya hal apapun hanya karena hal itu tertulis dalam kitab-kitab keagamaanmu. Jangan percaya hal apapun hanya karena hal itu dikatakan berdasarkan otoritas guruguru dan sesepuh-sesepuhmu. Jangan percaya tradisi apapun hanya karena tradisi itu telah diwariskan dari satu generasi ke generasi lainnya. Tetapi setelah kamu observasi dan analisis, maka ketika kamu mendapati hal apapun sejalan dengan akal-budimu dan menolongmu untuk mendatangkan kebaikan dan manfaat bagi satu dan semua orang, maka terimalah itu dan jalankanlah."165

Bagaimana usaha penanaman dan pembiasaan atau "budidaya mentalitas ilmiah" tersebut dikembangkan di dunia kampus STAKN Toraja? Ada ungkapan ala bisa karena biasa. Semua harus dimulai dari

${ }^{164}$ Cletus Groenen, "Peranan Alkitab dalam Teologi," Jurnal Orientasi Baru Vol. 3 (1989): 84

165 Gautama Budha, sebagaimana dikutip oleh Ioanes Rakhmat, "Fiksi dan Fakta Sejarah dalam Kitab Suci,"

http://ioanesrakhmat.blogspot.in/search/label/Fi ksi\%20dan\%20Fakta\%20Sejarah\%20dalam\%20 Kitab\%20Suci (Diakses 20 Juni 2017). 


\section{JURNAL PENDIDIKAN AGAMA KRISTEN}

kebiasaan sehari-hari yang melibatkan baik pihak dosen maupun mahasiswa. Pada lingkup dosen, apakah percakapan ilmiah masih ada? Ataukah seperti dikatakan oleh Reza Wattimena, para dosen masih sibuk dengan "takhayul" dan gossip?

Bagi para mahasiswa, apakah mentalitas ilmiah sudah dimiliki ataukah "mentalitas instan" yang masih mengukung cara pandang dan tindakan praktis sehari-hari termasuk dalam dunia akademik, misalnya melalui pengerjaan tugas yang asalasalan? Apakah semangat membaca buku masih ada ataukah hanya bermodalkan paket data dan koneksi Internet untuk melakukan copy paste dari website tanpa memberikan analisis kritis terhadap tugas-tugas yang diberikan?

Salah satu penyakit yang pelan-pelan namun harus diberantas adalah plagiarism. Plagiarisme adalah ketidakjujuran intelektual yang berasal dari kemalasan, ketidaktelitian, dan ketidakpedulian. Sebagai sebuah bentuk Kejahatan intelektual, Plagiarism mempertaruhkan Integritas seseorang sebagai seorang Kristen, teolog, dan (calon) Pendeta.

$\mathrm{Hal}$ ini berarti bahwa plagiarisme adalah dosa kaum intelektual. Siapapun bisa jatuh ke dalamnya. Plagiarisme berarti dengan sesuka hati mengutip sebuah sumber namun tidak mau mengakui bahwa tulisan atau karya yang dihasilkan merupakan hasil karya orang lain. Ada beberapa macam tipe plagiarism yang membuat kita sadar atau tidak ternayata telah melakukannya.
Akan tetapi, sebelum kita menyibukkan diri dengan ruparupa plagiarism tersebut, kita bisa memulai dari hal yang sederhana untuk menghindarinya. Cara tersebut adalah yang paling mudah dan sangatlah simple: cantumkanlah sumber atau rujukan yang anda kutip, entah dari buku, majalah, surat kabar atau internet yang bukan merupakan ide dan karya anda. Sederhana namun hal ini tentunya mengena dengan konteks dunia akademik di STAKN Toraja.

\section{Penutup}

Memerangi mentalitas malas, tidak peduli, dan enggan bekerja keras dalam konteks dunia akademik memang menyisakan tantangan tersendiri. Penyakit tersebut tidak hanya menjangkiti kalangan mahasiswa namun juga tenaga pendidik dan kependidikan. Hal ini berarti bahwa revolusi dengan menanamkan mentalitas ilmiah tersebut tentu tidak mudah namun bukan berarti tidak mungkin.

Di Indonesia sendiri pun, dikotomi Barat dan Timur seolah masih kental. Yang dimaksud Barat dan Timur bukanlah budaya Eropa versus Budaya Asia atau Afrika dan Amerika Latin, melainkan Indonesia Timur versus Indonesia Barat. Telah sekian lama berkembang pemahaman bahwa pendidikan di Indonesia Barat jauh lebih maju dibandingkan Indonesia Timur. Dalam kadar tertentu, kita mungkin bisa mengangguk kepala tanda setuju. Akan tetapi pada sisi lain, entah disadari atau tidak, kita sendirilah yang membiarkan dan cenderung 
memelihara mentalitas "lebih rendah, kurang maju, tidak berkembang itu."

Dalam konteks inilah seluruh elemen di dalam STAKN Toraja diajak untuk melihat hal tersebut sebagai cambuk untuk memotivasi diri. Mengajukan kritik terhadap diri sendiri, melakukan pertobatan untuk berusaha bangkit, maju dan mengembangkan mentalitas ilmiah sebagai bagian dari peran serta kita menyukseskan program pemerintah dengan moto yang semoga bukan sekadar moto, "revolusi mental."

\section{Daftar Pustaka}

Greene, A. E. A transforming vision: Reclaiming the future of Christian Education. Colorado Springs: ACSI, 1998.

Groenen, Cletus. "Peranan Alkitab dalam Teologi." Jurnal Orientasi Baru Vol. 3 (1989): 84-96.

Kadarmanto, Mulyo. "Mengkaji Revolusi Mental dalam Perspektif Pendidikan Kristiani." Polygot: Jurnal Universitas Pelita Harapan Vol. 12 No. 1 Januari 2016): 103-118.

Kominfo. "Revolusi Mental: Membangun Jiwa Merdeka Menuju Bangsa Besar," https://www.kominfo.go.id /content/detail/5932/revol usi-mentalmembangunjiwa-merdeka-menujubangsabesar/0/artikel gpr) (diakses 13 Oktober 2017).

Ord, David Robert dan Robert B. Coote, Apakah Alkitab Benar?, terj. Martin Lukito Sinaga. Jakarta: BPK Gunung Mulia, 2013.

Rakhmat, Ioanes. "Fiksi dan Fakta Sejarah dalam Kitab Suci,"

http://ioanesrakhmat.blo gspot.in/search/label/Fik si $\% 20$ dan $\% 20$ Fakta $\% 20$ S ejarah \%20dalam \%20Kita b\%20Suci (Diakses 20 Juni 2017).

Singgih, Emanuel Gerrit. Mengantisipasi Masa Depan. Jakarta: BPK Gunung Mulia, 2004.

Sitopu, Radjiman. "Pendidikan Nilai Bela Rasa Kristiani: Sebuah Perspektif Filosofis." Jurnal Proklamasi Vol. 6 (20042005): 5-30.

Wattimena, Reza A. A. Filsafat Sebagai Revolusi Hidup. Yogyakarta, Kanisius, 2015.

Wattimena, Reza A. A. "Revolusi Doa dan Revolusi Mental,.." https://rumahfilsafat.com/ 2014/05/13/revolusi-doadan-revolusi-mental/ (Diakses 13 Oktober 2017).

Wuisman, J. J. M. Pengertian Ilmuilmu Sosial. Azas-azas, Jilid 1. Jakarta: FEUI, 1996. 